\title{
Legal History Researcb in Belgium (2020)
}

Keywords: Belgium, legal history, conferences, books, $\mathrm{PhD}$ defences

\section{Introduction}

2020 was eventful, albeit not in a way anyone had expected or hoped for. Despite the circumstances, I hope this overview will reveal some positive notes from 2020, as I discuss some of the developments in legal history that have taken place in, or pertained to, Belgium last year. ${ }^{1}$

While this contribution will feature some notable conferences, publications, and $\mathrm{PhD}$ defences, I will try to keep it succinct. Conferences or published works that are not mentioned are therefore by no means insignificant. As far as conferences go, most of them have been postponed or cancelled due to the crisis caused by the COVID-19 outbreak. This necessarily means that an overview of these events is limited to the ones that were planned until the beginning of March, and to the digital ones, if such alternative was provided. Furthermore, the list of publications has been limited to books, since the inclusion of all contributions to journals, which have nonetheless undoubtedly brought many interesting insights, is beyond the scope of this paper. The books that are included have been co-edited or co-authored by scholars in legal history who are or were active at Belgian universities until at least 2020.

${ }^{1}$ This overview is based on the Rechtshistorische Courant, a monthly newsletter from the Institute for Legal History at Ghent University, from January to December 2020 and on the websites of the Belgian universities and of several organizations, notably of the Institute for Legal History (http://www.rechtsgeschiedenis. be; accessed: 31.03.2021). 


\section{Conferences and events}

The tradition of Roman law has played a significant role in the development of western legal society. One of the facets of Roman law with a lasting influence is liability law. For this reason, the impact of Roman law and of liability law in particular was the subject of the first of five sessions in the course cycle on Latin and Roman society (Facetten der Romeinse Oudheid), in which Roman society was explored through short Latin texts. The program was organised by Masereelfonds (a cultural foundation named for Frans Masereel), ${ }^{2}$ and took place in January and February.

On January $14^{\text {th }}$ Annemieke Romein (Ghent University until 2020, currently affiliated with Huygens Instituut voor Nederlandse Geschiedenis) held a presentation on her research on early modern police ordinances, comparing Flanders and Holland at the Gentse Rechtshistorische Causerieën, organised by the Institute for Legal History at Ghent University as an informal platform for younger scholars to present their research. She also elaborated on a project on digital legal history.

An exposition about the archive of the Imperial Chamber Court (Reichskammergericht), the ultimate civil court of the Holy Roman Empire for the principalities of Liège and Stavelot-Malmedy ${ }^{3}$ began in Liège, in the French speaking part of Belgium, in 2019, and finished February $2^{\text {nd }}$.

At the Leuven Legal History Talks, Boris Bernabé gave a lecture, titled "Piero della Francesca, Nicolas de Cues et la théorie canonique des présomptions".

On March $4^{\text {th }}$ and $5^{\text {th }}$ a colloquium on blasphemy, sacrilege, and violence took place at the liberal archive Liberas in Ghent, where court cases involving blasphemy were discussed, among others.

The following day, Andrew Bricker (UGent) talked about the interpretation of legislation on satire and slander by the English courts in the $18^{\text {th }}$ century at the causerie on libel law, "Words of a Contrary Signification': Libel Law and Satire in EighteenthCentury England" at the Institute for Legal History in Ghent.

2 Masereel (1889-1972) was not only a renowned Belgian artist, he was also known as an activist, committing to pacifism and social issues: Masereelfonds, 'Wie we zijn', https://www.masereelfonds.be/wie-we-zijn/ons-verhaal/ (accessed: 31.03.2021); and Frans Masereel Centrum, 'About', https://fransmasereelcentrum. be/en/about/ (accessed: 31.03.2021).

3 Baumann, Anette. "The Imperial Chamber Court (1495-1806) as an Educational and Training Institution”. In: Legal Literacy in Premodern European Societies, ed. Mia Korpiola, 43-58. Cham: Springer Nature, 2019, https://link-springer-com.kuleuven.ezproxy.kuleuven.be/chapter/10.1007\%2F978-3-319-96863-6_3 (accessed: 31.03.2021); State Archives of Belgium, Trésors de procedure. Les archives restaurées du Tribunal de la Chambre impériale (1495-1806), http://www.arch.be/index.php?1=fr\&m=actualites\&r=agenda\& $\mathrm{e}=$ tresors-de-procedure.-les-archives-restaurees-du-tribunal-de-la-chambre-imperiale-1495-1806 (accessed: 31.03.2021). 


\section{Books on legal history}

While the COVID-19 crisis may have brought an early halt to a lot of interesting conferences in 2020, it did not stop scholars from producing numerous works on a variety of different subjects, both legal historical and multidisciplinary, and pertaining both to Belgium and to the wider European and international context:

Wouter Druwé (KU Leuven) published his doctoral thesis on the normative framework on loans and credit in the Low Countries, Loans and Credit in Consilia and Decisiones in the Low Countries (c. 1500-1680).

Els Witte (VUB) published a book about the question as to why Belgium chose to become a constitutional monarchy instead of a republic, Belgische republikeinen: Radicalen tussen twee revoluties (1830-1850). She approaches this question from the perspective of the (then-considered) radicals fighting for democracy, universal human rights, and against the monarchy, who left behind ideas that would eventually grow into modern political movements.

Geoffrey Grandjean's (University of Liège) book about Émile de Laveleye (University of Liège) and his work on the principle of equality also came out in 2020. It is titled Le principe d'égalité dans l'organisation de la société. Émile de Laveleye - Un intellectuel au service de la Cité.

Alain Wijffels (KU Leuven/University of Leiden) and Louis Sicking (University of Leiden/VU Amsterdam) co-edited Conflict Management in the Mediterranean and the Atlantic, $1000-1800$, which treats different aspects of conflict resolution in the context of international trade. The work covers the Mediterranean and Atlantic areas through a legal comparative approach.

The role of the Belgian Court of Cassation has received thorough attention in Matthias Van Der Haegen's (University of Maastricht/Ghent University) book, Het Hof van Cassatie als lichtbaken van het Belgische rechtsbestel. In this work, Van Der Haegen analyses the role of the judge of the Court of Cassation in finding and determining the law. Although the genesis of this Court stems from distrust towards judges, this notion has lost much relevance in today's legal reality in Belgium. Van Der Haegen postulates suggestions in order to redefine the role of the Court and of its judges based on the results of his analysis.

A book offering a view across the Channel came from the hand of Caroline Laske (UGent), who published her monography, Law, Language and Change: A Diachronic Semantic Analysis of Consideration in the Common Law. Laske focussed on the evolution of terminology and semantics throughout legal doctrinal developments related to English contract law, and this work is therefore situated on the border between law (legal) history, and linguistics.

Continuing in the international setting, the second volume of Itinéraires d'histoire de la procedure civile, with the subtitle Regards étrangers, on the history of legal procedure from a multinational perspective, was published, complementing the first volume, entitled Regards français (published in 2014). The volume was co-edited by Loïc Cadiet (University of Paris 1), Serge Dauchy (UCLouvain Saint-Louis Bruxelles/Université de 
Lille), and Jean-Louis Halpérin (ENS), and it contains a contribution from Dirk Heirbaut (UGent) and Maarten Vankeersbilck (UGent) on the Belgian perspective.

\section{4. $\mathrm{PhD}$ defences}

At least four scholars have defended their doctoral theses on a legal historical subjects in Belgium:

Kaat Cappelle (promoted at VUB, Faculty of Law and Criminology; currently affiliated with Ghent University as a guest lecturer) successfully defended her doctoral thesis on the legal status of married women in $16^{\text {th }}$ century Antwerp (De strijd om de broek. Getrouwde vrouwen en recht in zestiende-eeuws Antwerpen).

Christophe Maes (promoted at KU Leuven, Faculty of Law) obtained his doctoral degree with a thesis on the concept of sovereignty in the Belgian Constitution and the interpretation thereof in the Constitutional Assembly of 1830-1831 and the subsequent Belgian legal literature until 1960, titled Het soevereiniteitsbegrip in de Belgische grondwet van 1831. Een rechtshistorisch onderzoek naar de betekenis van soevereiniteit voor de organisatie van de Belgische staatsmacht.

Maj Antonie Hartmann (promoted at KU Leuven, Faculty of Arts) defended her thesis, Politics in Publishing - Japan and the Globalization of Intellectual Property Rights, $1890 s-1970$ on the interaction between the Japanese publishing industry, legal experts, and the state in the context of the expansion of the application of the Berne Convention for the Protection of Literary and Artistic Works for the purpose of further protection of copyright.

Chanelle Delameillieure (promoted at KU Leuven, Faculty of Arts) defended her work on the legal aspects of late medieval marriage, titled Contentious consent. Abduction, control over marriage and legal strategy in the late medieval Low Countries. The goal of the project was to examine the parental and judicial control over the formation of marriage, with a particular focus on the cities of Leuven, Antwerp and Ghent. 